\title{
Annapurna Ma, Priestess and Healer: Women's Agency in Folk Culture of Rural Orissa
}

\author{
Elinor W. Gadon
}

\section{INTRODUCTION}

My paper ${ }^{1}$ explores issues of female agency within the context of popular religion in the folk culture of Orissa. June McDaniel in her study of ecstatic religion in Bengal suggests that religion has been both the way in and the way out...for women. It has been the way into a ritual tradition that supports subservience, lowered status, and a limited sphere of activity. But it has also been a way out, for religious knowledge and practice have given women freedom and a wide range of action... Religious experience serves to create and justify their religious status (1989:191).

The role of the holy woman allows the woman some freedom and self- determination. (McDaniel: 230). She has forged an independent spiritual life for herself following the commands of the goddess.

I write about the story one such woman, Annapurna Ma whom I encountered in the course of my field work, who serves her goddess, Sarangei, as a priestess and her devotees as a healer. Her very name meaning abundance is a most auspicious one in Indian culture. She is one of those women that can be found all over the subcontinent who fall outside the categories usually ascribed for religious functionaries like priests, shamans, sadhus or yoginis. Socially they are marginal, often but not always of harijan or low caste origins, usually raised in poverty, and illiterate, although sometimes not as ignorant of learning as they let on. They have no formal religious training, no gurus, no lineage. Their transmission and power come directly from the goddess. Their supernatural powers are recognized by a culture in which the boundaries between human and divine are very loose. They act on their access to the Devi's wisdom. As Annapurana says, "it is not me who heals, but the goddess". What is so remarkable about them in a society where women have little status or power is their agency. They too are called Ma or Mataji, and often venerated as a manifestation of the Mother Goddess, recognized as a living goddess.

Ma Annapurna is a gracious, attractive woman in her mid-forties who lives with her husband and family in an ample thatched-roof house by the side of the shrine of the Goddess Sarangei whom she serves. Shrine and home are located by the ruins of a vast ancient fort known as Sarangagadha still standing in the middle of paddy fields near the hamlet of Chodagangapura a few miles from the industrial town of Barang in coastal Orissa. The fort was probably named for the goddess. Sites of the sacred have lots of staying power in India, and there is a long tradition of the Devi manifesting herself and her powers at specific localities. The village is named for Chodagangadeva (1058-1125) who was considered to be the most powerful king of his time in eastern India. His initiation of the construction of the famed Jagannatha temple in the major pilgrimage center of Puri has earned him immortal fame in Orissan history.

\section{DESCRIPTION OF SHRINE, HOUSE AND LAND}

As we bumped along the narrow dirt road on our way to meet Annapurna, we first noticed the triangular red pendent, the mark of the goddess's presence, flying from the tallest branches of the tamarind tree on the little hillock under which her shrine sits. The shrine was immaculate, freshly painted inside and out, its interior in a warm blue providing a colorful background for the richly dressed and ornamented murti, the three dimensional figure of the goddess who was profusely garlanded with red hibiscus, yellow and white blossoms. A large nose ring is prominent on her black face, carved with sensitivity and beauty, the only part of her image that is visible. From what I could make out of the configuration under her garment, this is an icon of Durgamishamardini, representing the cosmic victory of the Great Goddess over the buffalo demon, Mahisha. At her side are two large uncarved stones, dressed and liberally smeared 
with red sindur, sporting metallic eyes, emblems of their power, aniconic forms of the Devi.

The surrounding landscape is very beautiful. We are in rich delta country, an idyllic pastoral setting with open fields, distant palms, and a nearby pond. Flocks of white herons fly in procession across the sky. The setting sun paints a rosy glow over everything. It was so peaceful, the silence only broken by the cries of the birds, occasional sounds of raucous crows and the wail of a distant train.

Ma Annapurna is well-off. Her ample and well-provisioned home is a most generous one by village standards. She has extensive vegetable gardens, fruit trees, some fifteen cows and goats. Her devotees reward her with gifts of kind and money.

\section{HERSTORY}

As soon as I saw her with her long matted locks I recognized her as someone possessed by the goddess. Jatas, matted hair, are symbolic of renunciants. Matted locks are a gift of the goddess when the woman has been accepted as a priestess and symbolic of her new status but while Annapurna is an ecstatic she is not an ascetic.

Annapurna is her given name. She was born in the village Daruthenga not far from the town of Barang, located about 14 miles from Bhubaneswar and famed for its glass manufacturing. She does not remember when the goddess whom she calls Ma first came to her early in her life but vividly recalls this experience. I quote:

"I was trembling and shaking with acute pain and my heart was not in a normal condition. The most interesting and frightening thing was my running here and there and roaming about with a roaring sound. My parents and sisters were very sad and unhappy when they were not able to control me. I am not sure that I was conscious in those childhood days... what was happening I cannot think and I cannot tell. And my mind along with Ma is not allowing me to think of those days...it is now very painful for me.

Some people were very happy seeing me in those days...thinking that a spirit has come to save mankind. Let her live healthy and strong. Saying so or thinking in this way they offered me fruits and milk and good food for my health. Some men were sad and telling my parents your daughter is sick and take her to a doctor. She will be mad soon; her mental health is disturbed and she needs care and also medicine. Some persons told that this girl needs to marry soon as she is sick of some kind of sex disease. Some other persons were silent and they were praying for me to become good and gentle”.

Possession is a cross-cultural phenomenon perhaps best described as any complete but temporary domination of a person's body and the blotting out of that person's consciousness by a distinct alien power of known or unknown origin often accompanied by illness or madness.

"So my mother and father decided to give me in marriage soon to this nice man who is my husband and everything to me. We have a big gap of age. He married me when he was 35 and I was 16. In our village area it is considered very normal".

Acceptance of marriage and the support of the husband is characteristic of these holy women in contrast to the celibate sadhika.

"At the beginning my husband worried as he did not know anything of my relation between the Goddess and me. As a young unmarried girl I had not known enough. Gradually my husband who was very good and kind understood more and more and my devotion towards him was also very important and he realized more and more the sweet relation between $M a$, the Goddess, and a devotee like me".

In time he began encouraging her to get the blessing of the Goddess when she came. His idea was to get and to capture her Shakti to do good for the people in this world.

But it was not easy for Annapurna. The goddess kept testing her.

"Ma was coming to me or we can say she was capturing me and keeping me under her control. I was not able to do my work. My inlaws abused me; they threw me into a well and tried to drown me. I ran away but Ma said no, I should go back because my husband was a good man. My first daughter was born, but the abuse continued so we moved out to Barang. I kept having dreams of this human looking woman with animals telling me to do puja. She talked just like we are talking. I didn't know what to make of it, neither did my husband".

Disturbing things continued to happen to her.

"At the Mother's request I went to Bhuhasuni temple at 3 A.M. in the morning. The priest began doing puja, then locked the door and started abusing me. I escaped out the window. 
The mali priest of the Singhabahuni Temple after telling me to go with him to a mela took me to a hilltop, asked me to take a bath so he could have sex with me. Again I ran away, this time naked. I never told her husband who was still sleeping. I kept asking Ma why are you sending me to these threatening situations, torturing me? In time she sent me to her shrine where I am now saying 'I am there and you do exactly what I say".

Annapurna was not certain who this Goddess was who wanted her to go to the masses and heal and save mankind.

"I was really running in a dark and blind curve where I did not know what to do and what to achieve and how to do good in society. Ma for me is a female deity... a goddess and as I had conceived and accepted HER as SHE is loaded with lots of energy and good qualities. And my desire was to be like that, a living spirit under the shade of HER enormous power and energy to spread her spirit to the masses. I cannot tell exactly the day and date when she began to come or when she accepted me fully and finally to be her real priest. I do not know yet-whether I have come to the final point of my achievement or is there anything which I will get to-day, tomorrow or day after tomorrow”.

\section{HER RECOGNITION: SAVING THE ELEPHANT}

Her supernatural powers were recognized by the people of her town when she saved the life of an elephant who was marooned in the deep waters of the flooded river. Again I quote her words as she related the event to me.

"During the floods in 1982, the nearby river Praci was very deep and there was lots of water. Seven elephants were going this way. One of them went into the river to take a bath and wash his body that was very dirty. He entered the river with great joy but after about ten minutes because of the clay and mud in the water it became very difficult for him to stand. He began to shout and finally the other elephants went to help their friend. They tried their best but it was fruitless. By the cry of the poor elephant people came from far and near and gathered on the riverbank. How to save the elephant! Nothing was possible for the elephant and the elephant man. They were in great trouble. A teacher was there, a friend of the family who had recognized that some great spirit was in me. So he ran to my door and asked me to come to see the elephant and save him from the river. I was staying at that time with my family in Barang town and my husband was working in the glass factory.

I told him it is impossible. I cannot do anything. I have no power, no supernatural power to save the elephant. But this teacher, named Mallik came to me and forced me telling me again and again many, many encouraging stories and trying to enliven me and my spirit. Then I told him that I am not pure now. I have my menstruation and it is my third day and I have not even taken my bath. Mr. Mallik said to me that this is good for this work, even it is the third day and you have not taken your bath there is no harm and the Goddess will be glad enough at this stage to load Her power and spirit. Saying so he gave me a fresh sari and took me from my home by his cycle".

Mallick's statement to her implying that her time of monthly bleeding was auspicious, a time of enhanced power for her, goes against deeply seated traditional taboos that a woman body is polluted when she is menstruating, that she must refrain from household duties like meal preparation and, must not participate in rituals. The heterodox Tantric tradition however acknowledges the power and auspiciousness of a women's blood.

Annapurna continues:

"I arrived at the river and I was surprised. Many, many men and women were waiting there for my arrival. I got down from the cycle and entered into the holy Praci river and took some water and sprinkled some to my hair and some to all the other sides in the ten directions, the digapals and then I went to the side of the elephant. I was standing on the river bank. I felt something and suddenly my mind began to whirl round and round and I felt the river bank to move from this side to that and keeping the elephant at a center I began to move in a circle. It was possible as there was a bridge and I encircled the elephant three times and than taking some flower and water from the river I remembered $\mathrm{Ma}$ and prayed Her and remembered that great power and spirit and requested my Ma even I do remember, I do not know which Ma it was. I know nothing. Then as soon as I threw the flower and water from my hand to the elephant (So nice to tell you, so pleasant to express) the elephant got up and came to the river bank on its own way from the clay and mud of the deep river. He was saved.

Everybody shouted with glee and joy and the elephant came along with its man to me. 
Suddenly the elephant lifted me up by its trunk and wanted to take me to the seat on it. But I refused and by the help of the elephant man he freed me from the trunk. And then the people of Barang came to my side and began to greet me with joy. They all shouted 'Jay Mataji, Jay Mataji.' At this sound and shout I fainted and lost my senses. After about 25 minutes I came to and saw that I was in the lap of my husband who was there helping me. Since then I have been accepted as a notable figure in this area. I became very glad for this".

Her experience in the river was a classic shamanic one. She was out of her body, out of her ordinary consciousness.

\section{FINDING MA}

Annapura Ma has gained recognition for her supernatural powers but she still doesn't know who her goddess was a few weeks later while walking alone at night through the nearby jungles and hills she found her goddess at last.

"I came to this Ma whom I had never seen earlier. I was found in the morning by the cattle herders and some other men who had come to gather firewood. They informed my husband who had been searching here and there in the city of Barbang with great fear. He came and with the help of others we carefully cleaned this place; dogs and cats had made it filthy, and I began my services here at Ma Sarangei. This was a very big thing for me and my husband. Since then I began a new way of living and got the chance to meet peoples of many different types, people of many different conditions starting from Harijans to Brahmins, young and old, male and female. I served mankind and I came to my deity properly as I am only a chakarani, a servant to Ma Sarangei".

\section{HER ROLE AS A HEALER}

Annapurna discussed her role as healer and the source of her healing powers:

"Many men and women, young and old come here for healing. But they are not of this area. They are from distant places like Cuttack, Balesore, Ganjam and Puri area. Some come from the capital city, Bhubaneswar. Nobody comes from the nearby Barang area. They come here. I treat them. I serve them. I offer them flowers and leaves of the deity and Her padukapani (holy water from her feet) but I do not cure them. Ma Sarangei cures and heals them. I am only
Her servant. She is my goddess and Ma and She cures by her grace and sympathy and because of their love and devotion. Ma Sarangei cures these people. She tells me to give this and that and I follow Her advice and do my needful duty. It is She who takes care and considers the love and devotion between them and they get back their health.

There is no set day, no fixed time to receive the devotee. They come at any time. They can pray and get the blessings at any time and it depends on Her sweet will to accept their prayer. It depends on Ma. Everyday is good for Ma. It is only trust and faith, love and devotion that helps and cures. Nobody tells me his or her problem. I tell them to pray to Ma and tell her their problems. It is their devotion and attraction towards Ma that persuades Ma to tell me to give them this or that flower or leaf and I do that following Ma's orders. The sick and sad unhealthy persons return from this place with great joy. They do not come back here again to thank me but I am not sad about this. I feel that they have been cured by the grace of Ma. I do not know their problems when they come. I only tell them to have the full faith and trust and love here before the Goddess to be cured. Whatever she gives for the sick and unhealthy persons who are her devotees is Her grace. I pass that on to them.

I know perfectly well that I am a servant of Ma. She is Goddess. She is Sarangei. I am human. I will do my duty and I will serve Her".

\section{AN EVENING PUJA}

I want to now describe her very exceptional performance during an evening puja.

The sun was setting and the whole area was growing dark. Gradually the stars in the clear sky became visible. Annapurna came out of her house dressed in a bright rose-colored sari. Her long matted hair was hanging in loose strands down to her waist. As she began her preparation for the puja, she arranged. the articles for her service by her side. Then she took her sari pleated in the customary way and tucked it up between her legs just like the male sadhus do. She completed her preparations sitting on the wooden pallet with her legs folded beneath her. The old man, her husband and the young boy, her son stood at either side of the shrine beating on a ghanta and clanging the jhanja, both heavy brass plates, in a loud and persistent rhythm that would continue until the service was over. She rose up and stood 
on her right leg, bending the left at the knee in an angle so that the left foot touched the right knee, standing in this posture for the full hour of the puja.

My collaborator, Purnachandra described the impact on him of her extraordinary presence.

Moving from side to side she was doing her service for the Goddess. It was beautiful and frightening. Her eyes were burning and glowing with power and loaded with spirit and energy that she had already received from her deity. She was looking to herself, not to any person. She was not looking to the pot in her right hand or to the bell in the left. Her eyes were not even towards the deity. Her eyelids were still and steady looking. They were open wide and steadily fixed somewhere. This continued for another fifteen minutes. It was now forty-five minutes and she standing only on the right leg, doing everything one after the other. When she finished the seva of arati she began to perform many kinds of gestures and postures before the deity turning around in all eight directions.

Next she took the chamara with its long thick black yak hairs and waving it began to dance to the sounds of the ghanta and jhanja. She was dancing on one foot; her left only helping to balance her body. Afterwards she walked to the empty fire pit nearby and then touched everyone with the long hairs of the chamara.

Purnachandra continues, describing the healing ritual that followed.

A women seated on the platform began to show her legs. Then Ma Annapurna began to climb on her legs, pressing hard, moving from their ankle to their thigh, as if drawing out their pain. She did it to one woman after the other and the women must have also felt lots of pain because of the weight of Ma on their legs.

Then Ma returned to her shrine and as soon as she climbed the steps her body stiffened and she fell to the ground. Her eyes closed and her lips were set tight. She was allowed to stay like this for ten minutes and then her husband and youngest son began to sprinkle some cold water on her face. They tried to lift her and to bring her outside to the open platform but were unable to do so by themselves. The devotees helped them to carry her to the laps of the women on the platform below who slowly opened her mouth and gradually gave her water. After about five minutes she came to and sitting up began to laugh a hearty laugh. The devotees one after another began to go back home. It was seven o'clock.

\section{CONCLUSION}

What are we to make of all this? How are we to understand Ma Annapurna's life and her role within the context of Hindu religion and culture? For one, this is popular, not Sanskritic, brahmanic Hinduism. Two, we have to acknowledge the wide range of practice that is possible in a religion that has no canonical form, no institutionalized hierarchy. Three, we need to step back for a moment and consider Western scholarship on the religions of India has been, giving pride of place to text while overlooking oral tradition and folk culture.

Within the cultural context of India, the most dramatic way in which the goddess manifests herself to her devotees is through possession, usually female, allowing the human vehicle to participate in her powers. Kathleen Erndl in her study of goddess possession in northwest India views it "...not as an isolated phenomenon but as a religious expression with the theological and ritual context of the goddess cult and popular Hinduism in general." She refers to the psychiatric definition "that in order for psychological states to be interpreted as possession and in order that sociological preconditions set the stages for such states there must be precise ideological correlates that anticipate perception of the phenomenon" (106). Such is the worldview of the popular culture of Orissa. The goddess is seen an agent herself, rather than simply as a disembodied symbol of projection (105).

I want to now single out three singular aspects of Annapurna's profile: (1) her matted hair; (2) her unusual posture while performing puja and (3) her use of Yagna, the Vedic fire ritual, usually the exclusive provenance of brahmin priests.

According to June McDaniel in her analysis of ecstatic religion in the neighboring state of Bengal, "religious experience serves to create and justify their religious status. In almost all cases, the religious experience was initially associated with madness or illness, and it was proven to be religious, not insane only after testing, devotion, miracle and the passage of time (191-192). Furthermore McDaniel suggests that the acceptance of marriage and the support of the husband, so central to Annapurna's mission is characteristic of these holy women (232).

The role of holy woman allows the woman some freedom and self-determination (230) She has forged an independent spiritual life for herself following the commands of her goddess. At first she was unable to identify the woman with the wild animals who appeared to her in her dreams. 
It was only when Ma as she refers to her deity, led her to the abandoned shrine of Sarangei that her goddess had a name.

This brings us to another interesting phenomenon in the religious experience of India, that of the mythic layering of the religious landscape. Sarangagadh was the name of Chodagangadeva's fort and the shrine of the Goddess was nearby its ruins. Which came first? Shakti, the cosmic force of the goddess traditionally locates itself in specific sites. One day when we were visiting Annapurna Ma she took us to a nearby place down the road and after digging a deep hole extracted what looked to me like black pebbles. Offering them to us, she confided that they were petrified rice left over from the Satya Yuga, a golden age, long gone by.

Ecstasy marked the possession of the dancer by the goddess. At the end the end of the puja, she collapsed into unconsciousness and fell like a lifeless statue. Was this her return to the void when the light faded away (237)?

Matted hair (jatas), are symbolic of the renunciant sadhu but while Annapurna is an ecstatic, she is not an ascetic. Anthropologist Gananath Obesekere has written extensively on the meaning of matted locks in the Sri Lankan context. According to him the gods show their love for her by gifts of matted hair and true prophecy (1981:1). McDaniel amplifies his interpretation in terms of the Bengali women she interviewed. Like the Sri Lankan women, they had been viewed as mad before they were accepted as holy. As was the case with Annapurna, "the Bengali holy women spoke directly to the deities and were possessed by them with little resistance." Like Ma Sarangei, "they were like good friends or parents, and gave advice and instruction" (233).

Another problematic is how are we to refer to her? Within the categories of popular Hinduism she is a priestess-healer. She is an ecstatic, not a sadhika. But this bears more investigation as to her conjugal relationship and as to just when did she first received her jatas. She informs us that the days when she became inauspicious, that is when she had her monthly bleeding, all those things are long gone by since she came to serve Ma.

How are we to classify the singular posture she adopted for puja or her use of the Vedic fire ritual the privilege of initiated brahmin priests? I can only suggest that with no religious training, she was self-initiated. Either she channeled through her goddess both form and content of her ritual or imaginative, clever, observant woman that she was able to create her own version. The first explanation is how her devotees and Indian culture would see it; the latter the explanation that of a pragmatic Western scholar. Straddling both views, I suggest that we still have much to learn about the mystery of the religious experience and I shall visit Ma Annapurna again.

KEYWORDS Devi; possession; priestess; shaman; healer; agency

ABSTRACT My paper explores issues of female agency within the context of popular religion in the folk culture of Orissa through a case study of one woman's empowerment, evolving independence and evolving social role. The role of the holy woman allows her some freedom and self-determination. She has forged an independent spiritual life for herself following the commands of the goddess. Such women fall outside the categories usually ascribed for religious functionaries like priests, shamans, sadhus or yoginis. Socially they are marginal. They have no formal religious training, no gurus, no lineage. Their transmission of power comes directly from the goddess. Their supernatural powers are recognized by a culture in which the boundaries between human and divine are very loose. They act on their access to the Devi's wisdom. As Annapurna says, "It is not me who heals, but the goddess." What is remarkable about them in a society where women have little status or power is their agency. They too are called Ma or Mataji, and often venerated as a manifestation of the Mother Goddess, recognized as a living goddess.

\section{NOTES}

1 I am indebted to my collaborators Dr. Rita Ray and Purnachandra Mishra for translations of the interviews. Dr. Ray accompanied me during visits to Annapurna Ma at her shrine in 2000 and 2001. Mishra returned in 2002 for additional interviews and obser vation of the rituals.

\section{REFERENCES}

Erndl, K. M. 1993. Victory to the Mother. New York: Oxford University Press.

McDaniel, J. 1989. The Madness of the Saints:Ecstatic religion in Bengal. Chicago: University of Chicago Press.

Obeyesekere, G. 1981. Medusa's Hair: An Essay on Personal Symbols and Religious Experience. Chicago: University of Chicago Press.

Author's Address: Elinor W. Gadon, Women's Studies Research Center, Brandeis University, Waltham, Massachusetts, USA

E-mail: elinorgadon2000@yahoo.com 